\title{
Does the Voice of the Learners Matter Under the Democratic Dispensation? The Trivialisation of the Learners' Voice in School Governance in the Rural Schools of Stutterheim, Eastern Cape
}

\author{
Nokuzola Gqeba ${ }^{1}$ \\ ${ }^{1}$ Faculty of Education, University of Fort Hare, East London, South Africa \\ Correspondence: Dr. Nokuzola Gqeba, Faculty of Education, University of Fort Hare, East London, South Africa. \\ E-mail: ngqeba@ufh.ac.za
}

Received: August 25, 2021

Accepted: September 25, 2021

Online Published: September 29, 2021

doi:10.5430/irhe.v6n3p38

URL: https://doi.org/10.5430/irhe.v6n3p38

\begin{abstract}
The ushering in of a democratic dispensation in South Africa in 1994 brought about significant changes within the education landscape. The South African Schools (SASA) Act of 1996 gave recognition and a voice to learners through formal representation in school governance. The article investigates whether learners' voice finds expression in school governance. The researcher adopted a qualitative research method where a phenomenological research was used. The phenomenological research was used in order to study experiences of stakeholders within the school environment in order to gain an insight on the participation of learners in school governance. Data was collected through conducting semi-structured research interviews. The sampled participants of the research were members of the school governing body, teachers and learners at the school and parents in the immediate vicinity of the school. The sample of the study involved ten parents, six teachers and ten learners and eleven members of the governing body. Data was analysed using coding where themes were developed and analysed to make meaning of the data. The study found that even though the Representative Council of Learners (RCL) was elected, it was never taken seriously by school management. The study also found that even though there were learners elected to the school governing body, their participation was of no significance. The study recommends empowerment of the learners so that they understand their role in governance.
\end{abstract}

Keywords: education, learners, governance, empowerment

\section{Introduction}

The education system in South Africa pre-1994 was characterised by racialisation and the existence of several departments of education. The learners were only there to be 'seen and not to be heard' as they played no part in school governance. Mncube (2009) (Mncube \& Mafora; 2013) contends that the apartheid government "used education to socialise young people into the existing status quo of inequalities through conformity to authoritarian structures". Under apartheid, even the finances allocated to black and white schools "were separated, and black children were given significantly less than white children." (Anwar, 2017) During the apartheid era, the education system in the country was a conglomeration of different sub systems divided on racial, ethnic and regional lines. The education system was complex with different structures. There were fifteen different ministries of education from independent homelands, six self-governing territories (non-independent homelands), one department responsible for Africans outside the homelands (Department of Education and Training) and one department responsible for Whites, Coloureds and Indians (one in each of the tri-cameral houses) (Hunt, 2014). During the apartheid era, the education system allowed for some form of community participation. This was through school councils, management or school boards. The school boards comprised of appointed and /or elected members from the local community. These councils, committees and/or boards played a consultative role in most schools (Hunt, 2014). What was common about this in all the sub-systems was the fact that only parents and no learners were part of these structures. It is for the reasons stated above that the learners rose against the system. It was mainly because of students being excluded in taking part in governance structures that the students protested. The Congress of South African Students (COSAS) was at the forefront of the uprisings. Amongst COSAS' objectives was "to participate in the drawing up of an educational policy framework for a future, non- racial democratic education system" (www.sahistory.org.za/article/congress-south-african-students-cosas). 
In their statement of beliefs, COSAS identified the following;

- "Students must be organised through democratically elected SRCs".

From its inception, COSAS was vocal about educational reform and an end to Bantu Education.www.sahistory.org.za/archive/committee/report-education-charter-campaign.These struggles by COSAS, and the South African Student Movement (SASM) were informed by the lack of voice in governance structures of institutions. Although in 1943 already, the ANC developed a document that they called the Africans Claims to protest against the Atlantic Charter. The Africans Claims contained a clause that spoke to education as envisaged by Africans. In it, the document says "The right of every child to free and compulsory education and of admission to technical schools, universities, and other institutions of higher education.;" (www.sahistory.org.za/archive/african-claims-south-africa-dr-xuma-anc-conference-1943) This was a recognition of the need to get rid of segregation in education and an acknowledgement of the fact that social transformation and true liberty are tied to quality education. The principle of free quality basic education was further enunciated in the Freedom Charter adopted in 1955 by the African National Congress, Congress of Democrats, South African Congress of Trade Unions and the Coloured People's Congress (the Congress Alliance). The Freedom Charter states that "Education shall be free, compulsory, universal and equal for all children" (www.marxists.org.za/subject/africa/anc/1955/freedom-charter.htm). The clause in the Freedom Charter was also informed by the fact that already when the Nationalist Party took over as the ruling party in 1948, they went to introduce Bantu Education Act in 1953 that legislated that African children should be afforded inferior education (www.sahistory.org.za/article/bantu-education-and-racist-compatmentalizing-education). Through their direct control of the education curriculum, the Apartheid government used education to entrench racial segregation and to brainwash Black children into believing that they were not South African citizens. Through Bantu Education, Black children were trained to be unskilled labourers to satisfy the demands of industry in a white men's world (Gallo, 2020). The passing of the Bantu Education Act solicited a lot of protests spearheaded by the ANC. The ANC showed its disdain for the Act by advocating that parents withdraw their children from schools. They also encouraged the raising of alternative funds to fund schools opposed the Bantu Education system.

\section{Literature Review}

\subsection{Learner Representation Globally}

Benner and Brown (2019) defines "student voice as student input in their education ranging from input into the institutional topics, the way students learn, the way schools are designed, and more". The assumption made by the two authors is that when the "student voice" is meaningfully increased, students take ownership of their education and that may be linked to improved student outcomes.

\subsection{Learner Representation in South Africa}

In South Africa student participation in governance is given effect to by the Children's Act and the South African Schools Act. The legislation referred to empowers child and youth care centres and schools to involve young people in governance. There is a difference between "government" and "governance". Governance refers to "the relationships and procedures that undermine how authority is exercised and resources are managed, how other role-players make their voices heard, and how those in authority are held accountable. Meanwhile, (Cheng, Leung, Yuen and Tang, 2020) define governance as "all aspects of the way the school is led, managed and run ... and the behaviour of its personnel and how they relate to each other." Conversely, "government refers to the institutions that govern, in South Africa, these include the national, provincial and local governments, the legislatures and the judiciary (www.gov.za/about-government/government-system/structure-and-functions-south-african-government). It was in this context that RCL's were formed. Morojele \& Muthukrishna (2011) posit that child participation in school governance, "is one of the fundamental rights of children embedded in the United Nations Convention on the Rights of the child". Amongst their responsibilities are, representing other learners, "to promote good relations and communication among learners, staff, and the school community, assist in maintaining order and promote responsible "learnership" (Pendlebury, 2011). It is within this context, institutions are bound to enable and provide for learner representation in governance structures (Klemencic, 2012). The learner's presence in governance structures within an institution is 'to safeguard the interest of the learners and present their views to the School Governing Body (SGB)' (Klemencic, 2012). Morojele \& Muthukrishna (2011) posit that "child participation" in school governance "involves supporting children to develop their own views, to think for themselves and to express their views effectively." 
Accordingly, (Cheng, Leung, Yuen and Tang (2020) posit that a student's participation in school governance contributes positively to a student's academic and social development. These (they argue) that this development includes the opportunity to learn the following "responsibility, trust, mutual respect, fairness, willingness to listen, openness to change, readiness to voice their opinions and take part in discussions". In identity is developed from taking part in out of the classroom experiences as well as through academics. It is within this context that (Pendlebury, 2011; Malan, 2010; Carter, Harber \&Serf, 2008) suggest that globally mechanisms are employed to involve learners in school governance as a form of democratising education. Post 1994 in South Africa when the democratic dispensation took effect, high schools were forced to have learner representation in school governance by the South African Schools Act of 1996. This enabled learners of a school to democratically elect the representation in school governance. The elected learner representatives (RCL's) were therefore taking part in school governing body meetings of schools and performing functions of the SGB.

These functions of the school governing body amongst the many that they are allocated by SASA include the drafting of school based policies. As members of school governing bodies, the RCL needs to be actively involved when such policies are drafted. Most often than not, the learners are not given an opportunity because they are seen as lacking experience in policy formulation and are immature to execute sound decisions that include them as learners. It is for that reason that (Nwosu \&Chukwuere, 2017) point out that the Act attempts to make sure that matured learners get elected into the SGB in that section 11(1) of SASA as well as section 23(4) require that a representative council of learners in a school are required to elect a learner representative in the SGB." Such a learner, should be in grade 8-12. The learners in the South African context have earned their right to participate in school governance having participated in the struggle for liberating South Africa. It is with this background that the learners were given an opportunity by SASA to take part in decisions that included and affected them such school based policies. Malan (2010) opines that the inclusion of learners in school governance through SGB "is the principal instrument for achieving transformation." It is within this context that the researcher examines the voice of the learner in matters pertaining to their voice in SGB's.

\subsection{The Notion of Democracy and Accountability}

Learners due to their limited experience in decision making are the ones who need to familiarise themselves with the proceedings in the SGB before they can actually assume an active role. Participation of learners in governance is a "tricky" business given the expectations as members of the SGB and their role as learners. Learners in the RCL do not only act as a mouthpiece for other learners, they also have a responsibility to assist in maintain order and to promote responsible "learnership" (Pendlebury, 2011). Therefore, the learner's voice in these instances matters.

\subsection{Governance and Representation}

Malan (2010) opines that "representativity is the principal instrument for achieving transformation". This was the case in South Africa in that learner representation signalled a break with the past repressive and authoritarian governance to a transformed democratic governance. Governance according to (Balarin, Brammer, James \& McCormack, 2014) refers to "the 'patterns of rule' which are concerned with regulation, direction and procedure" The reason for including learners as stakeholders in decision making originates from the global movements for increased youth participation in settings in which young people find themselves (Article 12 of the UN Convention on the Rights of the Child, 1989).

\section{Theoretical Development}

The researcher used involvement theory by (Foreman \& Retallick; 2013) to explain and understand the pivotal importance of involving learners in governance. The theory suggests that learners/ students that invest more time in classroom and non-classroom activities of the institution, are more prone to perform academically better. The involvement theory is also a stark reminder that the interests of the learner, in most cases are linked to the needs of the institution (Foreman \& Retallick; 2013). Even though the theory was developed after observing college students, the principle can equally apply to high school learners. If school management demonstrates keen interest in student life, there are greater choices of learners being more attached to the school and performing better academically.

\section{Research Problem}

Research undertaken on learner participation tended to focus on principles of democracy. This articles tries to take a different view by linking learner participation with the learner involvement theory. In this article the researcher sets out to investigate the learners' voice and involvement in policy making. My doctoral study investigated the conceptualisation of ulwaluko in school based policies in two selected schools in the Stutterheim area (Gqeba, 2020). The findings of the study revealed that the schools did not accommodate ulwaluko (male initiation) as a cultural 
practice that is undergone by the learners of the selected schools. This then revealed potential areas of conflict in the implementation of RCL involvement and school governance (Gqeba, 2020). Therefore, based on this background, the objectives of the study are as follows:

- To explore the contradiction between learners being part of policy formulation and them being subjects of the same policies they formulated.

- To investigate the laxity that learners have in freely expressing their voice within school governance structures.

- To identify potential obstacles to learners playing a significant role within school governance structures.

\section{Methodology}

\subsection{Research Design}

To investigate the phenomenon, the researcher adopted a qualitative interpretive research method where a phenomenological research was used. The phenomenological research was used in order to study experiences of stakeholders within the school environment in order to gain an insight on the involvement of learners in school governance. The purpose is to capture, analyse, interpret, and understand the experiences of learners, using their own interpretations.

\subsection{Data Collection}

Data was collected through conducting semi-structured research interviews. The sampled participants of the research were members of the school governing body, teachers and learners at the school and parents in the immediate vicinity of the school. The sample of the study involved ten parents, six teachers and ten learners and eleven members of the governing body.

\subsection{Data Analysis}

This section focuses on the interpretation of data gathered for the article. The researcher analysed the data using the thematic analysis approach.

\section{Discussion and Findings}

The voice of the learner within school governance was chosen as an area the article focused on given the fact that they are participating in governance structures including policy formulation and at the same time follow the same policies including cultural practices that are practiced within in their respective communities.

\subsection{Power Dynamics}

The study revealed that one of the obstacles to learners meaningfully participating in school governance is power dynamics within schools. Teachers use their positions of power to undermine /disregard and trivialise the learner voice in governance. Also, the fact that the learners depend on the very same teachers for academic assessments makes them reluctant to openly disagree with and /or openly criticise teacher's views. These conditions disempower learners from making meaningful contributions to school governance.

In reference to the above, Zuko, one of the learners interviewed asserted that,

"Participation in meetings with teachers is useless as our views get neglected. Nothing we say is ever taken seriously by the teachers".

Conversely, Siphosethu, another learner said,

"No learner can ever openly express their opinion in a meeting with teachers and parents as you would be viewed as disrespectful".

The other constraint faced by learners with regards to power dynamics is the limitations imposed by culture. In the African cultural context, young people are discouraged from speaking up or raising their voices to their elders. This makes it difficult for learners to argue for their views. The situation becomes worse with girl learners particularly in rural areas where women are expected to be subservient to men. This is expressed by Nokubonga, one of the girl learners as she reports that,

\section{"We as girls are never taken seriously, our voice does not matter".}

The quotation stressed the point that women are (culturally) expected to take the back sit, (Gqeba, 2020). 


\subsection{Cultural and Diversity Dynamics}

Another obstacle impending on learner's voice is that learners tend to discriminate each other in terms of age where younger learners in the school governance structure are often discriminated or excluded against by other learners. Learners also discriminate against each other and prevent others from assuming leadership roles on the basis of gender. Learners who are mostly on the receiving end of this discrimination are female learners, homosexual learners, transgender learners and finally those who have been not been circumcised, (Gqeba, 2020; Duka-Ntshweni, 2013; Gogela, 2017). Those who are initiated most often than not do not listen to those who have not been circumcised, this goes for parents as well (Gqeba, 2020; Gqeba, 2019). The above point is also emphasised by Mava, a circumcised learner,

\section{"We cannot let boys dictate to men what to do".}

Those who are not circumcised are referred to as boys (Gqeba, 2020; Duka-Ntshweni, 2013).

This is a sentiment shared by one of the SGB parents interviewed,

Mr Matshikiza, as he emphasised,

"We cannot be led by boys who are still wet behind the ears. What do they know about 'governing' a school"?

The other barrier to some learners assuming or participating in school governance activities is the rural / urban dichotomy. Learners with a rural background are often overlooked when issues are deliberated (by both learners and teachers) in favour of learners with an urban background. This is informed by the fact that in most instances, these learners from urban areas have a better grasp of issues. They have an advantage of being multi-lingual, (for instance, learners from Gauteng, who understand languages such as IsiZulu, Setswana, Sesotho, IsiXhosa and English).

\subsection{Workload Burden as an Impediment}

There are also those who argue against the participation of learners in school governance structures. They argue that allowing learners to participate in governance is tatamount to over burdening them. They argue that, it would be unfair and overburdening learners to expect them to take on an added responsibility of 'governing' on top of their academic responsibilities. One school principal interviewed argued that,

"It would be amiss of educators and parents to expect young minds who struggle to cope with their academic responsibilities to also be burdened with the responsibility of 'governing' with adults. The SGB meetings takes long and they sit often, this does not give learners enough time to study and do their school work".

Whilst on the other hand another teacher interviewed was of the view that,

"You cannot expect learners to be part of policy formulations whilst they are also expected to be subjects of the very same policies".

This is also a view of some parents who see learner participation in school governance as an abdication of responsibilities by educators. One parent who was interviewed, was of the view that,

"We send kids to school for them to be taught and to learn to write and not to run schools. Principals and their teachers must not abdicate their responsibilities to run the schools".

\section{Conclusion}

The article gives an account of the revolutionary process followed in the country for learners to have a voice in school governance. This is done by giving a background of the pre-democratic dispensation situation. Even though the author describes the watershed moment of learners getting representation and a voice in governance, the author also identifies challenges that prohibit learners from effectively participating in school governance. The article also makes recommendations on how learners can be empowered to meaningfully play a role in school governance. The article paves the way for more research to be conducted on creative ways by which learners can play a meaningful role in school governance. Whilst the research looked at the enabling legislation that gave rise to learner participation in school governance, there is space for further research to be conducted to delve deeper into the disjuncture between the intentions of the legislator and the lived experiences of learners.

Whilst it was easy to access the schools and that participants participated voluntarily and freely; the limitation was on the quality of the data received. There seems to be a lack of understanding on what the act means by the participation of learners in school governance. This is a potential limitation also for other researchers who wish to 
conduct research on policy and legislative matters in schools of that area. There is a potential for further research on issues relating to school governance and culture, race and age.

\section{Recommendations}

The issues presented in the findings of the data collected indicates that more needs to be done in terms of making sure that the learners voice in school governance is heard.

Learner empowerment

- This could be done by making sure that the Learners are empowered to recognise their constitutional guaranteed rights.

- Also, learners must be taught to take responsibility and take initiative.

- There should be a conscious effort by school governing bodies to empower the different categories of learners in their schools on impediments or obstacles to leadership. This could be done in order identify and circumvent such obstacles.

\section{Educator empowerment}

- Empowerment for educators is important so that the develop awareness on the role they play in disempowering learners from taking leadership responsibility.

- Educators to be empowered to capacitate learners to be able to play a role as the elected voice for their peers.

Parental empowerment

- Parents must be empowered to appreciate the cultural dynamics that play a role in the disempowerment of learners.

- It is also important that all stakeholders in education (Officials, school management, parents, learners and community) pay a special focus on learners with disabilities as they seldom have a voice in governance.

These recommendations can be realised if schools develop structured programmes for leadership development. These programmes should specifically focus on the following:

- Constitutionalism and democracy

- Basic leadership

- Communication skills

- Dispute resolution.

\section{References}

Anwar, M. A. (2017). White people in South Africa still hold the lion's share of all forms of Capital. The Conversation, University of Oxford.

Balarin, M., Brammer, S., James, C., \& McCormack. (2014). Governing our Schools. The School Governance Study, University of Bath.

Benner, M., \& Brown, C. (2019). Elevating Student Voice in Education. Center for American Progress, 14 August.

Carr, I., \& Williams, C. (2009). The mediation of representative council of learner's policy in Western Cape schools. South African Journal of Education, 29, 69-82. https://doi.org/10.15700/saje.v29n1a144

Cheng, K. C. E., Lueng, Y. W., Yuen, W. W., \& Tang, H. H. H. (2020). A model for promoting student participation in school governance. International Journal of Educational Management, 34(4), 737-749. https://doi.org/10.1108/IJEM-06-2019-0186

Department of Education. (1996a). South African School's Act. Government in South African Public Schools. Report of the Ministerial Review Committee on School Governance, Department of Education, Pretoria, Republic of South Africa.

DfES (Department for Education and Skills). (2004). Working together: Giving children and young people a say. Nottingham: DfES.

DoE (Department of Education). (1999). Guides for representative councils of learners. Pretoria: Government Printer. 
Duka-Ntshweni, N. (2013). Amakrwala experiences as learners in a Buffalo City secondary school: Implication for school leadership and management. University of Fort Hare, South Africa.

Foreman, E. A., \& Retallick, M. S. (2013). Using Involvement Theory to Examine Relationship between Undergraduate Participation in Extracurricular Activities and Leadership Development. Agricultural Education and Studies Publications, Iowa State University. https://doi.org/10.12806/V12/I2/56

Gogela, K. B. (2017). Perceptions of ulwaluko in a liberal democratic state: Is multiculturalism beneficial to AmaXhosa women in the Eastern Cape Province of South Africa?. Ph.D. Thesis. Rhodes University. Grahamstown.

Gqeba, L. M. (2019). Whispers from Skeletons. Jhb: National Library of South Africa.

Gqeba, N. G. (2020). The school governing bodies' conceptualization of ulwaluko in school-based policies: towards a deconstructed leadership and management framework, unpublished PhD Thesis, University of Fort Hare, East London.

Hunt, F. (2014). Learner councils in South African schools: adult involvement and learner's rights. Journal of Education, Citizenship and Social Justice, 9(3), 268-285. https://doi.org/10.1177/1746197914545928

Klemencic, M. (2012). Student representation in Western Europe: introduction to the special issue. European Journal of Higher Education, Routledge, England. https://doi.org/10.1080/21568235.2012.695058

Malan, K. (2010). Observations on representativity, democracy and homogenisation. Tydskrif vir die Suid-Afrikaanse Reg, (3), 427-449.

Mncube, V. (2009). The perceptions of parents of their role in the democratic governance of schools in South Africa: Are they on board?. South African Journal of Education, 29, 83-103. https://doi.org/10.15700/saje.v29n1a231

Mncube, V., \& Mafora, P. (2013). School governing bodies in strengthening democracy and social justice: parents as partners. Anthropologist, 15(1), 13-23. https://doi.org/10.1080/09720073.2013.11891288

Morojele, P., \& Muthukrishna, N. (2011, December). Child participation in school governance: The case of prospects at a school in Lesotho. Perspectives in Education, 29(4).

Nwosu, I. L., \& Chukwuere, E. J. (2017). The Roles and Challenges Confronting the School Governing Body in Representing Schools in the Digital Age. Journal of Economics and Economic Education Research, 18(2).

Pendlebury, S. (2011). Children and school governance: Representation, participation and power. South African Child Gauge, 44-48.

Retrieved from www.gov.za/about-government/government-system/structure-and-functions-south-african-government

Retrieved from www.marxists.org.za/subject/africa/anc/1955/freedom-charter.htm

Retrieved from www.sahistory.org.za/archive/african-claims-south-africa-dr-xuma-anc-conference-1943

Retrieved from www.sahistory.org.za/archive/committee/report-education-charter-campaign

Retrieved from www.sahistory.org.za/article/congress-south-african-students-cosas

\section{Copyrights}

Copyright for this article is retained by the author(s), with first publication rights granted to the journal.

This is an open-access article distributed under the terms and conditions of the Creative Commons Attribution license (http://creativecommons.org/licenses/by/4.0/). 